\title{
Need Analysis in the Development of English for Specific Purposes Learning in Students of STIA Prima Bone Administration Study Program
}

\author{
Abdul Rahman \\ STIA Puanggrimaggalatung Bone \\ Indonesia
}

Received: May 12, 2020

Accepted: Oct. 7, 2020

Published: November 1, 2020

doi:10.5296/jse.v10i4.17701

URL: https://doi.org/10.5296/jse.v10i4.17701

\begin{abstract}
This study aims to analyze students' needs in learning English and determine the learning methods used in learning English at STIA Prima Bone. This study uses a descriptive method with a qualitative approach. The subjects in this study were 60 students of the Public Administration Study program. They took courses in the second semester of the 2019/2020 academic year and one of the lecture language courses. The s lecturer sampling technique uses purposive random sampling. The instruments in this study were questionnaires and interviews. Based on the study results, the students' need for learning English in the Public Administration study program different or varied, so it can be concluded that they need English not only for current learning needs or Now Oriented but also for work needs (Future-Oriented). Therefore, learning English in the Public Administration Study Program must prioritize the target needs. So that, the fulfillment of wants can achieve and reduce the shortcomings or weaknesses of students in learning English. The teaching or learning method is an essential component in the educational process because the teaching process's success depends on the method used by the lecturer. The technique used in learning English courses in the public administration study program is to combine Student-Centered Learning, Teacher-Centered Learning, and Collaborative Learning.
\end{abstract}

Keywords: Need Analysis, ESP Learning Development, Students Need, English ESP. 


\section{Introduction}

The process of learning English with a specific purpose or known as English for Specific Purpose in higher education, often runs less optimally. One of the contributing factors is the lack of learning planning so that learning takes place not optimally by the field of knowledge being carried. For the development of English language teaching at higher education level required an English language learning model specific (English for Specific Purpose), so not only do the teaching model of English in general. This model of learning English must be done by looking at the learning needs in their respective fields. Judging from the benefits, the teaching of ESP in public universities is not very visible. It is indicated by the lack of mastery of English course material, which refers to the student's science field. Students only capture the lecture material limited to mastering vocabulary, English grammatical merely. In fact, in terms of its essence, teaching English in public tertiary institutions is directed at students' ability to speak, listen, read, and write.So far, English is a compulsory subject that must be undertaken by all students in the Public Administration Study Program in the first and second semesters.

What becomes a problem in teaching this English course is that the provision of material is more to the teacher's desires than to see the material needs desired by students so that more material is given in general or general English than in the field. Knowledge is carried out by students so that students lack the motivation to learn English. Even most of the students think that this English course is only a compliment because it is not by their expectations and their scientific fields.

It is essential to have a needs analysis of learning English according to students' needs and interests and the fields of knowledge they are currently studying. It is hoped that the results of learning English with this specific purpose can be applied and used. In the world of work. For the Administration study program, especially English language teachers, this need analysis can be the basis for implementing syllabus development in the next stage. For students, the existence of need analysis in this ESP can affect their learning motivation because the direction of learning English is more precise, more relevant, and by their field of study. Thus, it can make it easier for students to learn English, be it vocabulary mastery, pronunciation, speaking, listening, reading, writing, and structural, grammatical English.

\section{Literature Review}

\subsection{Needs Analysis}

Needs analysis is a systematic collection of specific information about students' language needs and analyzes this information for syllabus design (Robertson \& Jung, 2006). This needs analysis plays a critical role in designing and developing English lessons for ESP purposes. The process of needs analysis involves implementing Target Situation Analysis (what learners need with the language learned in the future), Present Situation Analysis (what learners can do with the language being studied at this time), and Context Analysis (how the environment in which the learning will take place). Information is needed from the needs analysis that has been carried out to improve the content and learning methods of ESP (Hossain, 2013) (Febriyanti, 2018). 


\section{Macrothink}

According to (Kareva, 2013) that needs must be determined by negotiations between the community and stakeholders. Furthermore, (Hutchinson \& Waters, 1987) presents the definition of need, namely by classifying conditions into target needs (what learners need to be able to communicate on target situations) and learning needs (what learners need to be able to learn). Furthermore, target needs are further divided into Necessities, wants, and lacks. Necessities are about what aspects of language do learners need. Lacks is what the learners haven't mastered. Wants are what the learners want to learn. This target situation analysis (TSA) is required for material from asking questions about the target situation and attitudes to all learners' position in the learning process.

This study focuses on the needs analysis proposed by (Hutchinson \& Waters, 1987) in (Saragih, 2014), (Otilia \& Brancusi, 2015) says that there are five groups of needs analysis from eight components that can be used in analyzing the needs of English learners. Namely:

a. Analysis of the target situation and analysis of the needs of the object.

b. Language analysis, discourse analysis, genre analysis, for example, knowledge of how language and skills are used in the target situation.

c. Analysis of the current situation: information about the learner's existing language use skills.

d. Learning needs analysis: language learning information about effective ways of learning skills and languages

e. Means analysis: information about the environment in which this course or subject is applied. 


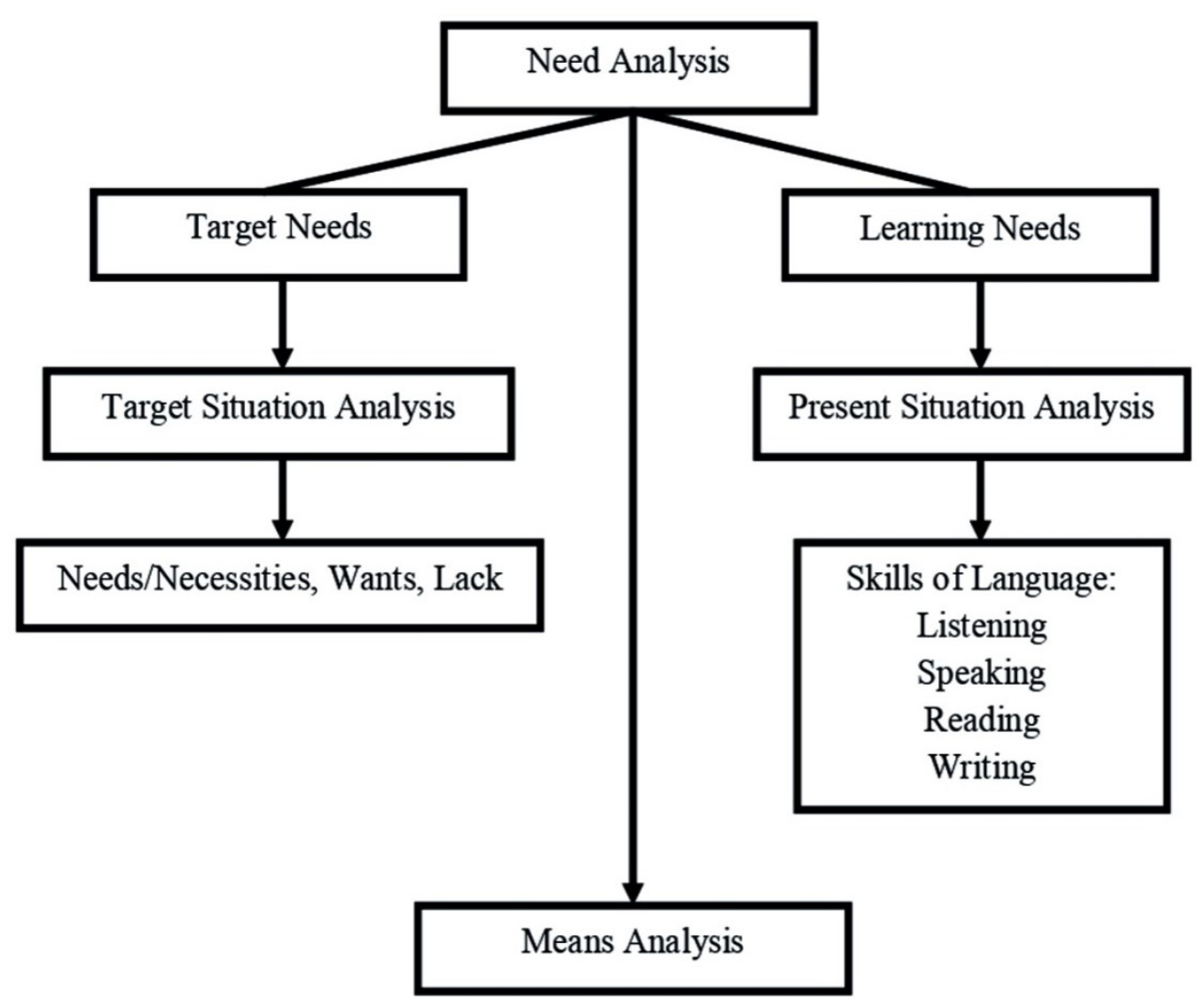

\subsection{ESP Learning Development}

Development is an effort to improve technical, theoretical, conceptual, and moral skills according to education and training needs. Product is a process of designing learning logically and systematically to determine everything that will be carried out in learning activities by paying attention to the potential and competence of students (Darmadi, 2017). Learning by (Hanafy 2014) is an activity that produces through the stages of design, implementation, and evaluation, defined as the interaction of learners with education and learning resources in a learning environment.

From the above understanding, it can be concluded that learning development is a systematic process, including problem identification, strategy development, and instructional materials, as well as evaluation of instructional strategies and materials in achieving learning goals effectively. So in this research, what will be developed is the syllabus, RPS, and materials or teaching materials that are by the needs of students. It makes them in the form of learning modules that can be used as reference materials for lecturers who teach English in the Administration study program. There is uniformity of the material being taught. 


\subsection{English ESP}

English for Specific Purpose is the teaching of English for specific purposes. According to (Rus 2019), defining ESP is an approach to language teaching in which all decisions as to content and methods are based on the learners' reason for learning. English for Specific Purepose is a language learning or teaching program where the content and learning objectives are determined by the specific needs of particular groups of students (Barnard et al., 2002) in (Agustina, 2010).

From the above opinion, it can be concluded that ESP is an approach to teaching that puts forward the needs or reasons of the learners learning English. ESP is described as teaching English for specific purposes as well as for specific professional goals.

\subsubsection{Characteristics of ESP}

As a new approach to learning English, ESP has different characteristics and characteristics from learning general English. Of course, these characteristics are also clearly and significantly different from other English learning, such as English as Second Language (ESL) or English as a Foreign Language (EFL).

According to (Paltridge\& Starfield 2012), there are three main characteristics of ESP that distinguish it from General English or English a Foreign Language (EFL) or English as a Mother Tongue (EMT). The three parts are:

- $\quad$ ESP is a goal-oriented learning (goal-oriented).

- The substance is ESP designed and developed based on the concept of needs analysis (need analysis).

- $\quad$ ESP is more aimed at adult learners than children or adolescents.

It is logical because ESP is generally taught at the intermediate and high academic and professional levels or the workplace.

\section{Method}

\subsection{Type of the Research}

The type of research is a descriptive study using a qualitative approach. Based on this, this study used a questionnaire from respondents. Students took English courses in the second semester of 2019-2020, and an interview with one of the English lecturers in the Public Administration Study Program as datato be analyzed descriptively qualitatively.

\subsection{Location and Subject}

This research was conducted at the STIA Prima Bone Campus. The research subjects were students of the Public Administration Study Program in the second semester of the 2019/2020 academic year, with 218 students. The sample in this study was 60 people, and the sampling technique was using purposive random sampling. 


\subsection{Research Procedure}

Procedure in this study is that the researcher distributes a questionnaire about the needs analysis of English learning to the second-semester students of the Public Administration study program. Then conduct interviews with English language lecturers as material for needs analysis students learning English.

\subsection{Research Instruments}

The instruments used in this study were questionnaires and interviews. The questionnaire form that is made is a closed-ended questionnaire, which is a question that has answers that can be directly selected by respondents. The questionnaire material refers to a list of items that lead to their necessities, wants, and lacks, and questions about their current English language skills. Besides, some of the questions on this questionnaire were also adapted from research (Adnan, 2012), which was then translated into Indonesian so that the samples could more easily understand and answer these questions. Then conduct interviews with English lecturers as materials for needs analysis.

\subsection{Data collection technique}

The technique used in collecting data in this research is through the distribution of questionnaires. It is considered the most appropriate to collect data on exceptional English learners (ESP) in tertiary institutions from non-English majors. And then conduct interviews with English lecturers as materials for needs analysis

\subsection{Data analysis technique}

After collecting research data from questionnaires and interviews, the two data will be analyzed. There are three steps to analyze the results of the data obtained from respondents, namely, precoding, coding, and summarizing (Given, 2012). The first step is precoding. Precoding is reading data and trying to find key ideas or problems related to the research question. At this stage, the researcher did different precoding for the questionnaire and interview. For the questionnaire, researchers looked for the frequency and percentage of participant responses. On the other hand, interviews are analyzed differently. That is because the interview produces recorded data, so the data must be converted into textual form. Therefore, interviews were transcribed into text before being categorized.

The next step was coding. Coding can be defined as marking information, main ideas, or problems to be identified easily. At this stage, the researcher reviews the report and classifies vital images or issues for each instrument. Besides, each data is compared separately so that the researcher can find a relationship between the problems.

The last stage is summarizing. Summarizing is the process of creating a synthesis from previous data. On the other hand, it is also done to draw a final statement to answer the research question. For this study, a summary is explained based on the distribution of the data. 


\section{MInstitute"}

\section{Results}

English is a general subject that must be passed by every student in the first and second semesters of the Public Administration Program. This course weights two credits per semester. The material presented in this course varies, and not all English teaching lecturers provide material according to student needs. It is difficult to unify students' requirements; the teaching lecturers cause it emphasizes the grammatical aspect than the development of students' skills such as speaking, listening, reading, and writing.

From the first question in this study, the researcher tries to see and determine the level of students' ability to learn English.

Table 1.The ability of students in the English

\begin{tabular}{ccc}
\hline Level & Number & Percentage \\
\hline Beginner & 45 & $75 \%$ \\
Intermediate & 9 & $15 \%$ \\
Advanced & 6 & $10 \%$ \\
\hline
\end{tabular}

Base on the data in table 1 above, it is clear that the average English proficiency students of Public Administration are taking courses in English 1 and 2 still on the ability of beginner 45 or $(75 \%)$, nine or $(15 \%)$ students consider themselves intermediate. Six or $(10 \%)$ students think advanced.

The second question is to find out why students learn English. If you look at the questionnaire results, most of the students are learning English because they need English for their careers. One of the English lecturers said the same thing that English is essential to be mastered by students, especially in facing globalization competition. Therefore, the students must be equipped with the right skills to compete in achieving their career targets in the future. Table 2 is the result of the answer to the second question.

Table 2. Student questionnaire results about their reasons for learning English

\begin{tabular}{lcc}
\hline \multicolumn{1}{c}{ Reason } & F & $\%$ \\
\hline Because English is a compulsory subject & 5 & $8.33 \%$ \\
Because I need English for my education & 13 & $22 \%$ \\
Because I need English for the career I want & 20 & $33,33 \%$ \\
Because I want to communicate fluently both orally and in writing & 11 & $18.33 \%$ \\
Because I need to learn TOEFL & 9 & $15 \%$ \\
Because English will broaden my knowledge and insight & 2 & $3.33 \%$ \\
\hline
\end{tabular}


In the table 2 above, the data obtained varies widely. There are 20 respondents $(33,33 \%)$ indicated that English is essential and needed for their careers, followed by their education 13 respondents $(22 \%)$, then for use in communication both orally and in writing 11 respondents (18.33\%), and then for learning TOEFL 9 respondents (15\%). From these data, it can be concluded that students of the public administration study program have various reasons for learning English, especially English for Specific Purpose (ESP). By the objectives of ESP English, namely, to prepare students to master English based on the fields they are studying and based on learners' needs, academic needs (now oriented), and the needs of the world of work (future-oriented).

The third question is to determine the English skills used by students in speaking or communicating with their friends. Students should be able to use English in everyday life; for example, students are required to practice and use English in communicating at campus. However, researchers found that English in the Public Administration study program is still lacking, mostly when students share both in class and outside the classroom. Below is a table of the results of student questionnaires about the use of language in communication.

Table 3. The results of student's questionnaires about the use of language in communication.

\begin{tabular}{ccc}
\hline Language & Frequency & Percentage \\
\hline Indonesian & 45 & $75 \%$ \\
English & 7 & $11.67 \%$ \\
Indonesian \& English & 8 & $13.33 \%$ \\
\hline
\end{tabular}

Based on the table above, it is clear that most of the students use Indonesian in communicating with their classmates or about $75 \%$, and only $11.67 \%$ use English in speaking, and $13.33 \%$ combine English and Indonesian in framing. So, it is clear that students still need to improve their English ability because they think that English is essential for their career targets. Table 4 illustrates the results of respondents' answers about the importance of English skills to support their career targets.

Table 4. The importance of mastering the ability to learn English for student career targets.

\begin{tabular}{lcccccccc}
\hline \multirow{2}{*}{ Skills } & \multicolumn{2}{c}{ Very Good } & \multicolumn{2}{c}{ Good } & \multicolumn{2}{c}{ Fairly Good } & \multicolumn{2}{c}{ Weak } \\
\cline { 2 - 9 } & F & $\%$ & F & $\%$ & F & $\%$ & F & $\%$ \\
\hline Listening & 11 & $18 \%$ & 12 & $20 \%$ & 22 & $37 \%$ & 15 & $25 \%$ \\
Speaking & 9 & $15 \%$ & 13 & $22 \%$ & 18 & $30 \%$ & 20 & $33 \%$ \\
Reading & 17 & $28 \%$ & 7 & $12 \%$ & 27 & $45 \%$ & 9 & $15 \%$ \\
Writing & 12 & $20 \%$ & 15 & $25 \%$ & 16 & $27 \%$ & 17 & $28 \%$ \\
\hline
\end{tabular}

From the table above, we can see that the average ability of students regarding their skills is very different from the results of the data obtained. Most of the students felt that their powers 
were Fairly good in the reading skill (45\%), then listening (37\%), and some students were weak in the speaking talent (33\%) and the writing skill (28\%). Therefore, English lecturer must reproduce material that is more focused on speaking and writing skills, including productive abilities. According to students, it was difficult for them to master these skills due to a lack of vocabulary and not being able to master grammar well. In English, the Four skills are related to each other.

Various ways are required to motivate them to master English language skills to understand what students need in learning English for each skills. Many things can be done to improve the ability and skills to master English, one of which is reading many English books. Table 5 shows the types of needs that students must read to improve their English skills.

Table 5. What to read in English

\begin{tabular}{lcc}
\hline \multicolumn{1}{c}{ Needs } & F & Percentage \\
\hline Articles, Journal & 4 & $6.7 \%$ \\
English books & 12 & $20 \%$ \\
Magazines and newspapers & 2 & $3.33 \%$ \\
Lecture materials & 11 & $18.33 \%$ \\
Read literature related to the field of science & 31 & $51.7 \%$ \\
\hline
\end{tabular}

Table 5 above shows that about $51.7 \%$ choose to read literature related to science, $20 \%$ choose English books, $18 \%$ select lecture materials, and 6.7\% articles, journals, and 3.33\% magazines and newspapers. So it can be concluded that students need English to read and understand not only English-language books and lecture materials but also those related to their field of study.

Table 6. What to listen in English

\begin{tabular}{lcc}
\hline \multicolumn{1}{c}{ The aims of listening } & F & Percentage \\
\hline Understanding instructions/commands & 3 & $5 \%$ \\
Understanding videos / movies / songs & 26 & $43.33 \%$ \\
Understanding speeches or lectures & 8 & $13.33 \%$ \\
Understanding seminars or scientific presentations & 2 & $3.33 \%$ \\
Understanding lectures & 21 & $35 \%$ \\
\hline
\end{tabular}

From table 6 above, it can be explained that the students need listening skills to understand videos/films/songs (43.33\%), then understand lectures $(35 \%)$, understand speech/lectures 


\section{Macrothink}

(13.33\%), understand instructions / commands 5\% and finally is understanding scientific seminars/presentations $(3.33 \%)$.

The next skill that lecturers must consider in teaching English, specifically in the Public Administration study program, is writing skills.

Table 7. Writing skill needed in English

\begin{tabular}{lcc}
\hline \multicolumn{1}{c}{ The aims of writing } & F & Percentage \\
\hline Write emails & 0 & $0 \%$ \\
Writing research reports & $2 \%$ & $3,33 \%$ \\
to Translate Indonesian to English & $5 \%$ & $8,33 \%$ \\
Writing summaries & 0 & $0 \%$ \\
Make a note of the English language lecture & 6 & $10 \%$ \\
Writing business letters/job applications & 13 & $22 \%$ \\
Communicating through writing with other people about your field of \\
knowledge
\end{tabular}

table 7 shows that students learn English because they need writing skills to communicate written with other people about their field of study (40\%) and write business letters/job applications. (22\%). And they don't need it to write emails and summaries in English.

The eighth question is to determine students' needs in learning English (ESP) on speaking skills. These results can be illustrated in table 8 below. 
Table 8. Students Needs in the speaking skills

\begin{tabular}{llc}
\hline \multicolumn{1}{c}{ The aims of speaking } & F & Percentage \\
\hline For presentation & 7 & $12 \%$ \\
can participate in discussions in class & 11 & $18: 33 \%$ \\
can communicate with others about the field of science & 32 & $53.33 \%$ \\
can make questions and give answers in the classroom & 8 & $13.33 \%$ \\
Can speak in seminars or international conferences & 0 & $0 \%$ \\
Can speak with friends/people who come from abroad. & 2 & $3.33 \%$ \\
\hline
\end{tabular}

Based on the data obtained, it shows that students need speaking skills to be able to communicate with others about their chosen field of science $(53.33 \%)$ or can use English in class discussions (18.33\%). It can be concluded that students need speaking skills in English not only to be used as direct communication but also to support students to increase their knowledge of their field of knowledge.

The next question is to find out the aspects needed by students in learning English. We can see from the results of obtaining data in table 9 below: 
Table 9. Aspects needed by students to be studied in English courses

\begin{tabular}{|c|c|c|c|c|c|c|c|c|}
\hline \multirow{2}{*}{ Category } & \multicolumn{2}{|c|}{$\begin{array}{c}\text { Very } \\
\text { important }\end{array}$} & \multicolumn{2}{|c|}{ Important } & \multicolumn{2}{|c|}{$\begin{array}{c}\text { Quite } \\
\text { important }\end{array}$} & \multicolumn{2}{|c|}{$\begin{array}{l}\text { Not } \\
\text { important }\end{array}$} \\
\hline & Total & $\%$ & Total & $\%$ & Total & $\%$ & Total & $\%$ \\
\hline Reading fast and effectively & 15 & 25 & 39 & 65 & 10 & 17 & 0 & 0 \\
\hline Pronunciation & 40 & 67 & 11 & 18 & 15 & 25 & 0 & 0 \\
\hline Punctuation & 10 & 17 & 45 & 75 & 5 & 8 & 2 & 3 \\
\hline specific vocabulary & 35 & 58 & 15 & 25 & 17 & 28 & 0 & 0 \\
\hline General vocabulary & 21 & 35 & 35 & 58 & 7 & 12 & 0 & 0 \\
\hline $\begin{array}{l}\text { Writing sentence properly and } \\
\text { grammar correctly }\end{array}$ & 19 & 32 & 25 & 42 & 17 & 28 & 0 & 0 \\
\hline Make paragraphs organized & 12 & 20 & 41 & 68 & 7 & 12 & 0 & 0 \\
\hline Make notes from lectures & 19 & 32 & 27 & 45 & 10 & 17 & 4 & 7 \\
\hline Translate / Translation & 33 & 55 & 17 & 28 & 10 & 17 & 0 & 0 \\
\hline Learn Grammar & 37 & 62 & 22 & 37 & 1 & 2 & 0 & 0 \\
\hline $\begin{array}{l}\text { Listening and understanding } \\
\text { material related to the field of } \\
\text { science }\end{array}$ & 13 & 22 & 44 & 73 & 3 & 5 & 0 & 0 \\
\hline Spelling & 25 & 42 & 29 & 48 & 6 & 10 & 0 & 0 \\
\hline $\begin{array}{l}\text { Speak fluently about the field } \\
\text { of science }\end{array}$ & 46 & 77 & 9 & 15 & 5 & 8 & 0 & 0 \\
\hline $\begin{array}{l}\text { How to do the presentation } \\
\text { properly }\end{array}$ & 21 & 35 & 35 & 58 & 4 & 7 & 0 & 0 \\
\hline TOEFL strategies and exercises & 41 & 68 & 15 & 25 & 2 & 3 & 0 & 0 \\
\hline
\end{tabular}

Based on the table 9 above, the average student states that all aspects are essential to learning all of the elements attached to this question. Especially speaking fluently according to the field of science $(77 \%)$, TOEFL strategy and exercises (68\%), pronunciation $(67 \%)$, Learning Grammar (62), unique vocabulary according to the field of science / unique language (58\%), and translating (55\%). On the other hand, from some of these aspects, some students think that learning English is about making notes from lectures (7\%), and punctuation (3\%) is not essential to know. 
The tenth question is to find out whether the English course being studied is by student expectations or not. The results can be seen in Table 10 below:

Table 10. students' expectations of ongoing English learning.

\begin{tabular}{ccccccccc}
\hline \multirow{2}{*}{ Subject } & \multicolumn{2}{c}{$\begin{array}{c}\text { Very } \\
\text { Appropriate }\end{array}$} & Appropriate & \multicolumn{2}{c}{$\begin{array}{c}\text { Quite } \\
\text { Appropriate }\end{array}$} & \multicolumn{2}{c}{ Not Appropriate } \\
\cline { 2 - 10 } & F & $\%$ & F & $\%$ & F & $\%$ & F & $\%$ \\
\hline \multirow{2}{*}{ English } & 15 & $25 \%$ & 12 & $20 \%$ & 20 & $33,33 \%$ & 13 & $22 \%$ \\
\hline
\end{tabular}

From the results of the data collected, there were 15 (25\%) students who stated that they were very suitable as desired, $12(20 \%)$ students indicated that they were appropriate, $20(33.33 \%)$ students stated that they were entirely reasonable. There were $13(22 \%)$ students who stated it is not.

\section{Discussion}

Student Needs towards learning English

Learning English in college should be a concern for the lecturer of English and the campus to prepare students to face this globalization era. Therefore the analysis is needed to see how the needs of students in learning English. As it is known, English teaching must be emphasized on the aspect of developing communication skills in the field of science that students pursue not only in the grammatical part but combining all skills in English.

One approach that can be taken by teaching lecturers of English courses is focused on the learners' needs or, in other words, learning exceptional English or English for a Specific Purpose. Because ESP is more focused on language content than teaching grammar, through is an approach, a lecturer can analyze the students' needs, namely Needs, Wants, and Lack. It needs to be done so that students' English learning materials can match the needs of the field of knowledge they are capable of and the area of work they will pursue.According to (Zahid Javid, 2015) (Febriyanti, 2018), a certain proficiency level in the language is required to actively participate in learning content-related material. Based on the data obtained about the English language skills of students of the Public Administration Study Program, it can be said that the students' ability in speaking English still needs to be improved or their capabilities are still at the beginner level. In this case, the English teaching lecturer must be more careful in arranging the learning material given to students. That is because every student has different abilities in learning English. It is one of the difficulties faced by English lecturers who teach in the study program Non-English department to formulate material according to science students need. I interviewed one of the English teaching lecturers, who said that one of the efforts to increase students' English proficiency was by providing guidance and training.

On the other hand, needs analysis is related to wants or desires, namely what students want to learn English. Based on the data obtained, it shows that the purpose of students learning English is to prepare their career targets. Therefore, teaching English in the Public 
Administration Study Program must align with what English needs in the workplace. So there is a need for learning English focused on preparing graduates to compete in the world of work.In terms of communication, most students still use Indonesian when they are learning English instead of using English. That is because students think that they are still weak in speaking English. According to students, English is complicated to master because it requires mastery of useful vocabulary and grammar. If it is related to the student's ability to master English skills for their career targets, they are still weak, especially in speaking aspects and writing. Teaching these two skills is not an easy thing to do. In one class, the number of students exceeds 40 people, so in the teaching process, the lecturer can't invite every student to speak one by one actively.

Furthermore, based on the data obtained, one of the obstacles that make students weak in writing skills is due to the dense number of students in one class. They also lack vocabulary, so that when the lecturer gives assignments or writing exercises in English, not all students can do and finish well. Consequently, both skills it has not received enough attention. There are several reasons why students feel weak and have difficulty in speaking and writing skills in English. According to (Aleksandrazak 2011) states that speaking problems experienced by someone, especially students, are due to the tendency to formulate utterances in their mother tongue first before pronouncing them in English. Based on the results of interviews with English teaching lecturers, it was said that most students felt English was difficult for all skills, but the most difficult, according to students, was the ability to speak and write. That is because they lack vocabulary, both those related to general vocabulary and specific vocabulary by their field of study. Not only that, but the students also think that the factor of memorizing and pronouncing language is also a problem for them to communicate using English.

Furthermore, for writing skills, This skill is also considered very important and needed by students in learning English. Later, they can communicate in writing with other people about their field of study, and students can also write business letters and job applications in English. Therefore, English lecturers must develop unique English learning materials (ESP) properly and must determine the focus of teaching on which students in the classroom need skills. Therefore, to meet the target needs, learning English in the Public Administration study program must be further improved, especially combining the four English skills, the most important is the ability to speak and write. In other words, both gifts, this is by the needs of students for their future careers. According to (Macalister et al., 2020), Another way of looking at needs is to make a significant division between current knowledge and required knowledge and objective conditions and subjective requirements. Lacks according to current knowledge, Necessities according to the required expertise, and Wants according to personal needs.

Learners' goal to learn English in tertiary institutions, primarily non-English study programs, is more focused on developing skills English language with specific disciplines. Based on the data obtained about the students' expectations of the English learning that is being undertaken. Around $58 \%$ of students stated that they were by their expectations, $35 \%$ were very suitable, and $7 \%$ were quite right, none of the students indicated that they were not appropriate. It 
shows that students have varied needs and different characteristics. By the interview results, the English lecturer said that learning English must be improved and developed again so that graduates can have quality skills in terms of speaking English to compete in the current era of globalization. If you look at the results of student data about the reasons they learn English varies widely, they have different goals in learning English courses; some are more focused on current learning or Now-Oriented) and the world's needs of work or Future-Oriented. For current education, students learn English for their educational needs, communicate well orally and in writing, and need to learn TOEFL. As for the world of work, students need to know English for their careers and add and broaden their horizons about English.

Teaching English in the Public Administration study program is the essential thing that must be done by learning lecturers is to conduct a needs analysis to be able to analyze why English courses are taught and see what is needed by learners. If you look at the overall results of student answers, an English lecturer needs to develop and provide appropriate material to achieve the desired goals. The field of study must arrange the material they are engaged in so that it is useful so that they can use English in their future work world. According to (Chovancová 2014) states that for material development, namely, the teacher or syllabus designer must consider the use of material related to the learners' real life, namely authentic material that reflects their specialization. From this statement, it can be concluded that the preparation of materials like this can help students who have weak levels of English skills or beginners in developing their English language skills. Special English (ESP), which is taught in the Public Administration Study Program, will not only focus on one and two skills but combine four English skills and increase vocabulary memorization both about general vocabulary and unique vocabulary. With the development and preparation of authentic material, students will feel happy and relaxed in learning because the material presented is fun and needed.

Based on the results of students' statements regarding the need for English in each skill, it varies widely. They want things related to the field they are engaged in; for example, in reading skills, they prefer to read literature related to their area of knowledge and read books in English. Furthermore, for listening skills, they need English to listen to or understand videos/films/songs in English, understand lectures, and understand speech or courses in English. For writing skills, students need English to communicate in writing with others about their fields of study, write business letters, and write job applications in English. As for the speaking ability, students need English so that they can use it in communicating both talking about the field of science in English and in the process of discussing in class

Furthermore, about what aspects students need in English courses. Based on the data obtained, speaking fluently about the field of science is an important priority, and it is by the results of the answers received on the previous question. Then they learn English to master TOEFL strategies and exercises, master pronunciation, learn grammar, vocabulary that is by the field of science, and then translate.

Based on these answers, it can be concluded that students need an activity that can improve the quality of their English skills, such as English language training activities, increasing 
practice rather than theory. And that more important is to use a language laboratory in learning English.

\section{English for Specific Purposes Learning Method}

The teaching or learning method is an essential component in the educational process because the success of a teaching process depends on the lecturer's method. Moreover, in teaching English for specific purposes (ESP) in tertiary institutions where students do not come from the English language study program, but students of the Public Administration study program. (Adnan, 2012) states that ESP teachers have the right to use any technique or learning method in the hope of encouraging and helping their students to set their goals and plan for their future in learning. Meanwhile, according to (Zahid Javid, 2015), no one single teaching method is sufficient to answer the diverse needs of specific English learners, so that lecturer must choose from a variety of appropriate teaching methods depending on practical, specific English learning objectives.

From the results of interviews with English lecturers in the Public Administration study program, he said that the method used in teaching English is to focus more on Student-Centered Learning. It requires students to be creative, innovative in developing the material provided to be more active, and feel involved in the English learning process to create a fun learning. Students can be motivated to learn English for Specific Purposes. Not only that, according to the teaching lecturer, apart from using this method, sometimes the lecturer also combines the teacher-centered learning and collaborative learning methods in teaching English. So from the statement above, it can be concluded that the use of the technique in teaching English depends on the teaching lecturer seeing the student's needs in learning. Therefore, lecturers of English courses can decide on the next step, namely developing a syllabus. This step is crucial to choose the skills and components in English that should be given priority to students. Several essential points must be considered: the characteristics of various student needs, learning goals and styles, student motivation, and desires that are not the same. Based on the description above, it can be concluded that learning English in the Public Administration study program must use an attractive method and according to the needs of learners to create learning that can motivate students to learn English. Therefore, learning English in the Public Administration Study Program must prioritize the target needs (Needs / Necessities). The fulfillment of wants can be achieved and thus will reduce the shortcomings or weaknesses or lacks students in learning English.

\section{Conclusion}

Based on the research results above, it can be concluded that students of the Public Administration study program have different or varied needs in learning English. The difference is caused by their learning styles, their attitudes, and motivation in learning, and the learning strategies they use are different. From the four English language skills analyzed in this study, learners' ability or talent is considered a power needed in learning English as the main priority for their career. Learning grammar and memorizing vocabulary related to the field of study and general language is also necessary to improve learners' quality in mastering speaking and writing skills. Therefore, this study's results can be used as a reference in 
developing English learning in the Public Administration study program, namely in developing learning tools such as syllabus, Semester Learning Design, and completing materials or teaching materials according to the needs of learners. This needs analysis can also be used as an evaluation of the ongoing learning process. In addition to analyzing learners' needs, the results of this study also indicate that the teaching method used in this English course is more student-centered or, in other words, Students Centered Learning combined with Teacher-Centered Learning and Collaborative Learning methods.

\section{Recommendation}

English for particular purposes is a new approach in teaching and using English for specific fields and studies that are by the needs of science and the professions of English users. It is referred to as the needs of students and graduate users themselves. Needs analysis is a crucial step taken by teaching lecturers of English courses and especially in the Public Administration study program, to see students' needs in learning English. Teaching English in the Public Administration Study Program needs serious attention by looking at various aspects that can determine the success of mastering English. The most important is that it can help students support their careers. Furthermore, to produce quality graduates who can master English both spoken and written, it is recommended that the campus and study programs provide support for English language learning facilities, especially fixing language laboratories to support good English learning.

\section{References}

Adnan, S. (2012). Needs Analysis : A Process to Improve the Learning of ESP at the College of Administration- The Department of Administration and Economy- University of Basra

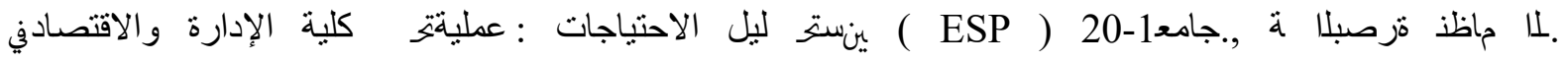
https://www.iasj.net/iasj?func=fulltext\&aId=62389

Agustina, T. (2010). ESP ; An Approach of English teaching for non English Department students. Beta, 3(2), 100-117.

Aleksandrazak, M. (2011). Problems and challenges in teaching and learning speaking at advanced level. Glottodidactica (Poznań). https://doi.org/10.14746/gl.2011.37.3

Barnard, R., Richards, J. C., \& Rodgers, T. S. (2002). Approaches and Methods in Language Teaching. TESOL Quarterly. https://doi.org/10.2307/3588247

Chovancová, B. (2014). Needs analysis and esp course design: Self-perception of language needs among pre-service students. Studies in Logic, Grammar and Rhetoric. https://doi.org/10.2478/slgr-2014-0031

Darmadi. (2017). Pengembangan Model dan Metode Pembelajaran dalam Dinamika Belajar Siswa. In Deepublish.

Febriyanti, E. R. (2018). Identifikasi Analisis Kebutuhan Pembelajar Bahasa Inggris (Non Program Studi Bahasa Inggris) Pada Mata Kuliah Bahasa Inggris Esp Di Lingkungan Fkip Universitas Lambung Mangkurat Banjarmasin. Vidya Karya, 32(2), 123. 


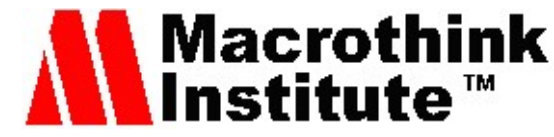

https://doi.org/10.20527/jvk.v32i2.5230

Given, L. (2012). The SAGE Encyclopedia of Qualitative Research Methods. In The SAGE Encyclopedia of Qualitative Research Methods. https://doi.org/10.4135/9781412963909

Hanafy, M. S. (2014). KONSEP BELAJAR DAN PEMBELAJARAN. Lentera Pendidikan: Jurnal Ilmu Tarbiyah Dan Keguruan. https://doi.org/10.24252/lp.2014v17n1a5

Hossain, J. (2013). ESP Needs Analysis for Engineering Students: A Learner Centered Approach. Journal of PU, Part: B, 2(2), 16-26.

Hutchinson, T., \& Waters, A. (1987). English for Specific Purposes: A learning-centred approach. https://doi.org/10.1017/CBO9780511733031

Kareva, V. (2013). English for specific purposes : Public administration and political sciences. Procedia - Social and Behavioral Sciences, 70, 1477-1481. https://doi.org/10.1016/j.sbspro.2013.01.214

Macalister, J., Nation, I. S. P., Macalister, J., \& Nation, I. S. P. (2020). Language Curriculum Design. In Language Curriculum Design. https://doi.org/10.4324/9780429203763-1

Paltridge, B., \& Starfield, S. (2012). The Handbook of English for Specific Purposes. In The Handbook of English for Specific Purposes. https://doi.org/10.1002/9781118339855

Robertson, E. P., \& Jung, J. (2006). Data-Driven Learning, Concordancing, Collocation. Asian EFL Journal, 8(4).

Rus, D. (2019). Assessment Techniques in Teaching English for Specific Purposes to Engineering Students. Procedia Manufacturing, 32(January), 368-373. https://doi.org/10.1016/j.promfg.2019.02.227

Saragih, E. (2014). Designing ESP Materials for Nursing Students Based On Needs Analysis. 6(4), 59-70. https://doi.org/10.5296/ijl.v6i4.5983

Zahid Javid, C. (2015). English for Specific Purposes: Role of Learners, Teachers and Teaching Methodologies. European Scientific Journal, 11(20), 1857-7881. 